\title{
境界要素法による高速移動荷重列に対する橋栴 の動的応答解析の試み
}

\author{
白旗 弘実 ${ }^{1}$ ・ 三朴 千暿 ${ }^{2}$ ・舘石 和雄 ${ }^{3}$ \\ 1学生員 工修 東施工業大学 大学院 博士課程 \\ 2 正会員 工博 東京了:業大学教授 工学部土木工学科 \\ 3正会員 工博 東京工業大学講師 工学部土木工学科 ( $\bar{\top} 152$ 東京都目黑区大椆山 2-12-1)
}

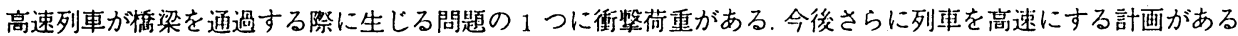
が, 徒来のモード法をべースにした解析法によれば, 高速域で, 衝慗率が極めて高くなることもある. 本研究では 彷来あまり試みられたことのない移動荷重による桥梁の動的応答を弾性波動から検討する目的で, 境界要素法を 用いた解析を試みたものである。
\end{abstract}

Key Words : impact factor, modal analysis, boundary element method, superposition

1.はじめに

新幹線の高速車両の試作, 磁気浮上式鉄道の開発にみ られるように, 列車のますますの高速運転が計画されて いる.このような高速化により，橋梁の動的応答が大き くなることが予想される.現状の新幹線橋梁の設計にお いては, 列車の速度, 桁の支間長, 桁の基本固有振動数か らなる速度パラメータを求め, それがある値より大きい とき, 動的応答の数值シミュレーション解析を行うこと になっている ${ }^{1)}$. 数值シミュレーション法としては, 松 浦により提案されたモード法をべースとした方法を基碟 とし2，これにさまざまな拡張が行われている3)，4)，5). この方法で時速 $550 \mathrm{~km} / \mathrm{h}$ の磁気浮上式鉄道のシミュ レーションを行うと衝慗率が 10 倍ほどになるとも報告 されている5)。このような高速鉄道車両と橋梁との動 的応答が実際に生じるかどうかは不明であり，また現在 では実験的に確認することはかなり困難である。ここで は，従来のモード重权合わせ法とは異なるアプローチに よる境界要素法を適用して高速域で列車, 橋梁の動的応 答の検討することを試みたものである。

\section{2. 従来の数值シミュレーション法}

構造物のモデル化としては単純支持の桁橋を対象と する.橋軸方向に $x$ 軸をとり, 桁下方変位を $y$ とする.

この変位 $y$ は式(1)のように表される.

$$
y(t, x)=\sum_{i_{b}=1}^{n_{b}} f_{i_{b}}(t) h_{i_{b}}(x)
$$

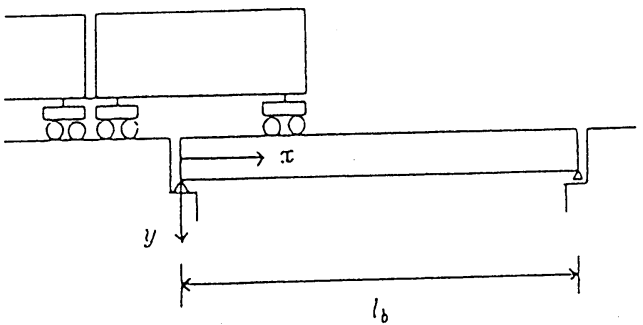

l. 支間長

$m_{b, i_{b}} \quad i_{b}$ 次の等価質量

$c_{b, i_{b}} \quad i_{b}$ 次の等価減衰係数

$k_{b, i_{b}} \quad i_{b}$ 次の等価ばね定数

图-1 解析対象

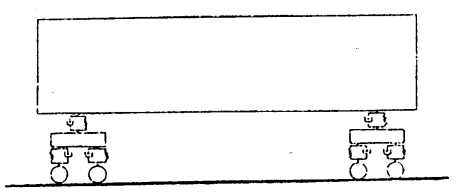

図-2 車両モデル

$$
m_{b, i_{b}} \ddot{f}_{i_{b}}+c_{b, i_{b}} \dot{f}_{i_{b}}+k_{b, i_{b}} f_{i_{b}}=\sum_{i_{w}=1}^{n_{w}} P_{i_{w}} h_{i_{b}}\left(x_{i_{w}}\right)(2)
$$

ここに $f_{i_{b}}$ は基準座標， $h_{i_{b}}$ は正弦波で表される基本振 動形, $m_{b, i_{b}}$ は $i_{b}$ 次の等価質量, $c_{b, i_{b}}$ は $i_{b}$ 次の等価減 衰係数, $k_{b, i_{b}}$ は $i_{b}$ 次の等価ばね定数, $x_{i_{w}}$ は $i_{w}$ 番目の 車軸の位置, $P_{i_{w}}$ は $i_{w}$ 番目の車軸の接地力, $n_{b}$ は考慮 する最高振動次数, $i_{b}$ はその番号, $n_{w}$ は車輪の数, $i_{w}$ 
表-1 林の諸元

\begin{tabular}{|c|c|c|c|}
\hline$l_{b}(\mathrm{~m})$ & $m_{b}(\mathrm{t})$ & $c_{b}(\mathrm{~kg} \mathrm{sec} / \mathrm{cm})$ & $k_{b}(\mathrm{~kg} / \mathrm{cm})$ \\
\hline 10 & 75.0 & 202 & 333000 \\
\hline 15 & 112.5 & 202 & 222000 \\
\hline 30 & 225.0 & 202 & 111000 \\
\hline
\end{tabular}

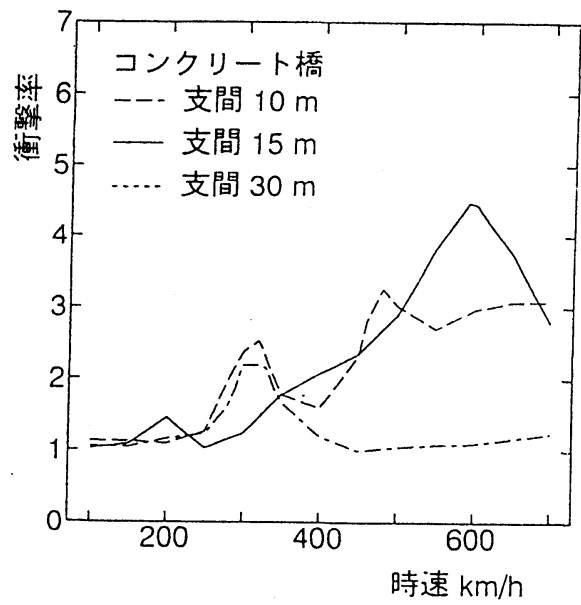

図-3 衝撃率と速度の関係

はその番号である. $210 \mathrm{~km} / \mathrm{h}$ の速さまでは新幹線で の実測值があり 2)，この理論に基づいた計算結果とよ く一致している.

図1 は数値計算のモデルとなる桁であり，図-2 は車 両のモデルである。これは新幹線車両をモデルとして おり, 車両長は $25 \mathrm{~m}$, 台車中心間距離は $17.5 \mathrm{~m}$, 台車 内車軸間距蜼は $2.5 \mathrm{~m}$ である。 また自由度は車体重心 の上下方向と回転角, 台車重心の上下方向と回転角, 車 輪軸の上下方向で 1 車両あたり,10 となる。この図は 1 両分だけを示しているが, 計算ではこれらが数両速結 された荷重列である. また, 表-1はそれらの林の諸元で ある.これらの值は文献 2)の実測値にあうように選ん だ. 図-3は 4 両編成の新幹線車両モデルが杕を通過し たときの応答を橋長, 速さを変えて求めた衝慗率のなか で，大きな值となるときの解析例である。ここでは，振 動モードを 3 次まで考愿している，ある点 $x$ における 衝慗率 $I$ は静的变位を $y_{s}$, 動的変位を $y_{d}$ として, 次の ように表される。

$$
I=\frac{y_{d}}{y_{s}}
$$

短支間のもののほうが衝繋率が高くなる傾向があり，列 車の速さが $300 \mathrm{~km} / \mathrm{h}$ をこえると衝撃率は急激に大き な値をとり, $600 \mathrm{~km} / \mathrm{h}$ にもなると，その値は 5 にもなる ような大きな衝慗が発生することになる。この解析法 の仮定として,桁の上下方向の変位は基本振動形と時阔
の関数の積の重ね合わせで求めており，桁の内部変形は 考慮されていない2)。ところが実際の現象としては, 载 荷に伴って载荷点近傍でまずひずみが発生し，それが弾 性波となって伝播している、列車の速さが速くなるほど この影㿟が無視できなくなると考えられる.

ここでは，実際に 5 をこえるような大きな衝慗率と なるのか，あるいはそれらを制御する方法はないのか， などについて検討するための基脴的な資料を求めるた めに, 従来とは全く異なるアプローチとして, 波動伝播 から橋梁の通過車両に対する動的応答を考えることに した。

\section{3. 境界要素解析による移動荷重動的応答解 析}

弾性波動問題としてこの問題を解析する。 そうした 解析方法として, 有限要素法動弾性解析 ${ }^{4)}$, 境界要素法 があげられる. 弾性波の速さは列車の速さに比べ, 非常 に速く数 10 倍ほどである．有限要素法を用いてこのよ うな条件下での動的応答解析を行おうとすると，要素の 縦横比が数 10 倍となる.

以上の理由から，ここでは境界要素法を用いることと した. 時間域での境界積分方程式は次のように表される。

$$
c_{i j} u_{i}=-\int_{S} T_{i j} * u_{i} d S+\int_{S} U_{i j} * t_{i} d S
$$

$U_{i j}(x, t ; y, \tau), T_{i j}(x, t ; y, \tau)$ は基本解であり ${ }^{6)}$ ＊は時 間以関するたたみ込み皘分である。 $c_{i j}$ は境界のなめら かさに関する係数である. 境界上の変位 $u_{i}$, 表面力 $t_{i}$ を蓶散化する。

$$
\begin{aligned}
& u_{i}(x, t)=\sum_{q=1}^{Q} N_{q}(x) \sum_{m} \phi^{m}(t) u_{i ; q}^{m} \\
& t_{i}(x, t)=\sum_{q=1}^{Q} N_{q}(x) \sum_{m} \psi^{m}(t) t_{i ; q}^{m}
\end{aligned}
$$

$\phi^{m}(t), \psi^{m}(t)$ は時間に関する補間関数である. $N_{q}(x)$ は形状関数であり，境界は $Q$ 個の独立した節点を持つ 要素に分割されるものとする，なお変位に関する空間 補間は一定とし，時間に対しては一次補間, 表面力に対 する空間に対しては一定，時間に対しても，一定として いる.

列車の通過を表現するためには各時間ごとに荷重の作 用点が変化する境界条件を与えることが必要となるが， 境界要素法でこの条件を満たすように計算を行うこと はかなり複雑になる.そこでここでは図-4に示すよう な重ね合わせによる方法をとった. 洔刻 $t$ で, ある車輪 が姴素 $j$ 上にあるとし，次の時刻 $t+\Delta t$ で次の要素に 移動するものとする. $\Delta t$ の間は要素 $j$ には等分布荷重 が作用しているものとし，これをステップ荷重の重ね合 


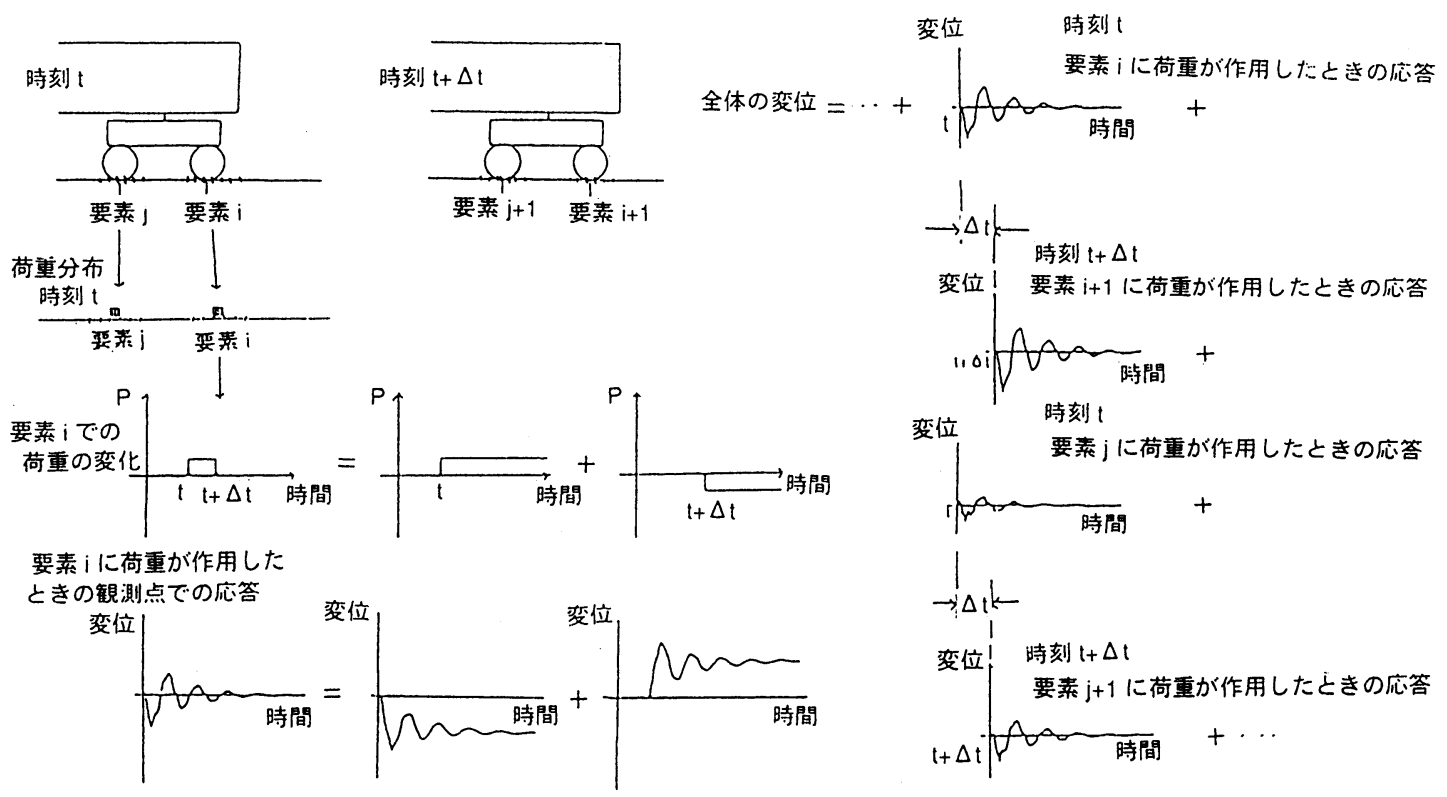

図-4 列車の通過の表現

解析対象
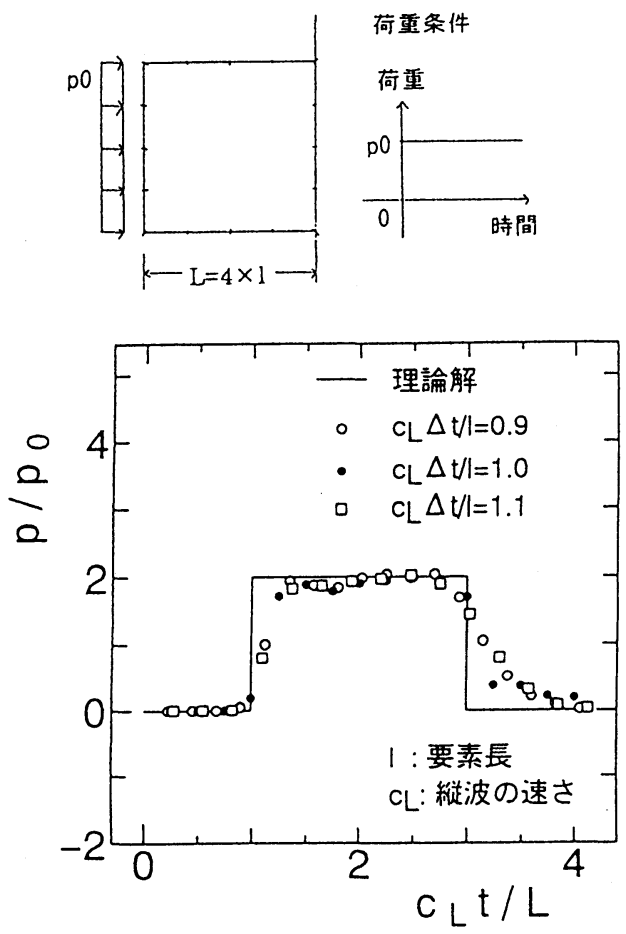

图-5 棒の縦振動の反力変化
わせとして近似したここれは表面力に関する補間を要素 一定としたからである。それでその間の応答を，それら のステップ荷重による応答の重ね合わせ,つまり，時刻 $t$ 以降載荷したときの応答から時刻 $t+\Delta t$ 以降载荷し たときの応答をひくことにより求めた．そのステップ荷 重の大きさはここでは等荷重分布列としている. また車 軸間の距蜼などは先に述べたものと同じである．動的 解析法の解の挙動, 安定性に影響を与えるものとして時 間きざみ幅, 補間法などがある. 䢃密な証明はなされて いないが時間きざみ幅 $\Delta t$ は要素長 lを波速 $c_{L}$ で割っ たもの，がよいとされている. 波面の前面となるところ では基本解に特異性が生じるが，これが数值積分点近傍 になると計算の精度がよくなくなることも原因の一つ と考えられている．図-5は棒の縦振動解析で，時間きざ み幅 $\Delta t$ をかえながら行ったものであり，この時間きざ み幅つまり $c_{L} \Delta t / l=1.0$ ととるのがよいことがわかる。 要素長は伝播する波の波長の約 4 分の 1 以下にとる ことが必要といわれている7).よって入射波長がどのく らいになるかを考えなければならないが，一般にコンク リートスラブなどの構造物に剛性球を落下させたとき の衝撃荷重の継続時間は $60 \mu \mathrm{sec}$ 程度であるといわれ

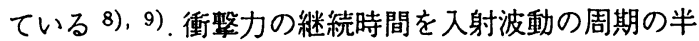
分と考えると、コンクリート中の弾性波速度も考虑して 波長を計算すると $36 \mathrm{~cm}$ になる。この約 4 分の 1 の值 として 1 要素長を $10 \mathrm{~cm}$ とした.

\section{4. 解析結果}

(1) 単位ステップ応答

図-6に要素分割を示す．長さ $5 \mathrm{~m}$ のコンクリート桁 


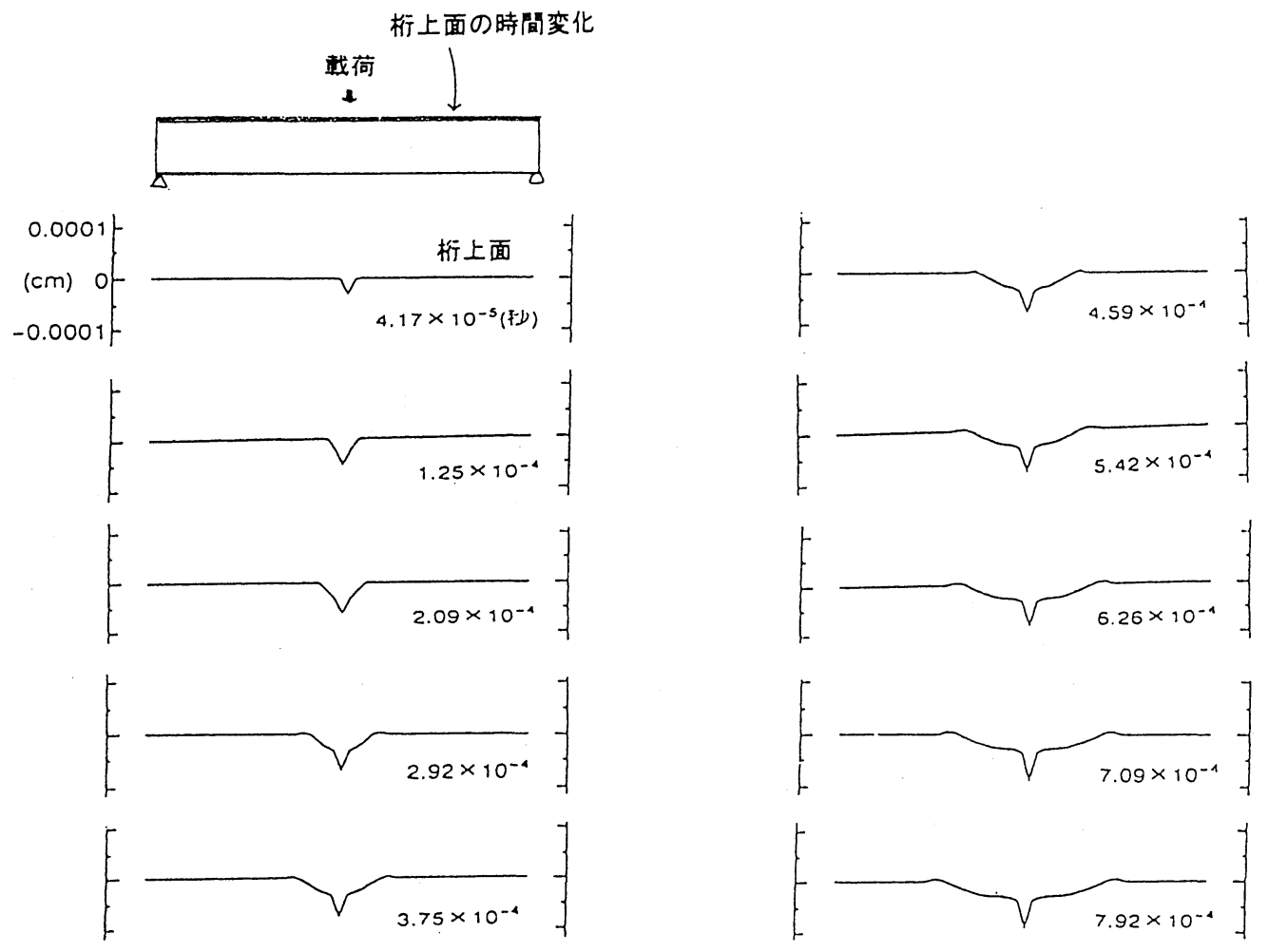

图-7 林上面の成荷直後の変形の時間変化
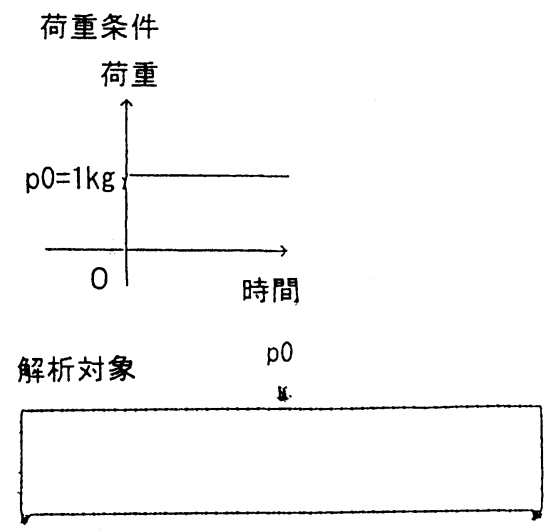

図-6 要素分割と荷重条件

を対象として動的解析を行った. 長さ $5 \mathrm{~m}$ とした理由は 計算機の容量による．図-7は桁の中央に単位ステップ 荷重を載荷したときの桁上面の鉛直方向の変位の時間 変化を示したものである.時間とともに変形が広がって いくのがわかる. また, 载荷点の変位はまわりの变位と 比較して，大きいものである。これは桁を従来のような 1 次元変位場ではなく, 2 次元変位場として計算したか らである. 図-8 はその後の桁の全体の変形を示したも のである. 図で $2.76 \times 10^{-2}$ 秒後あたりの変形がもっ
( $10^{-4} \mathrm{~cm}$ (变位)
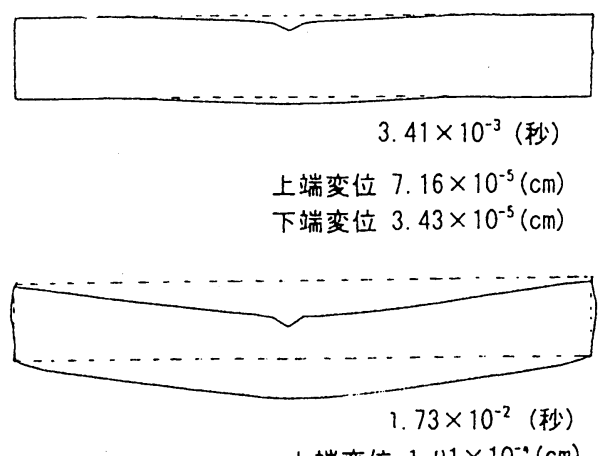

上端变位 $1.91 \times 10^{-4}(\mathrm{~cm})$ 下端変位 $1.82 \times 10^{-4}(\mathrm{~cm})$

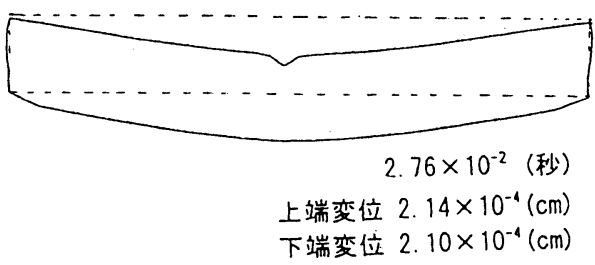

図-8 桁全体の変形

とも変位が大きいときである，単位衝整の計算で, 時間 ステップが大きくなると，数值積分誤差の伝播により 


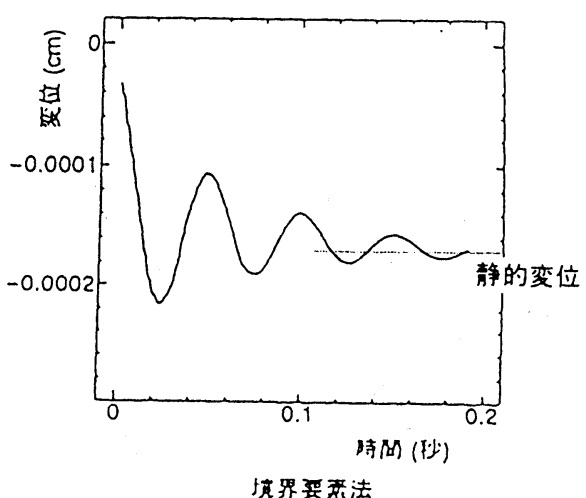

図-9 単位ステップ応答

解が数值的不安定現象をおこす．これを防ぐために, 耀 散化を施した式に粘性項 $\sum D \Delta u^{m}$ を加えた。ここで $\Delta u^{m}$ は $u^{m}-u^{m-1}, D$ は減衰を表すマトリックスで ある.この不安定現象をおさえるのに減衰を $5 \%$ ほど にしている.この粘性項については後に考察を加える.

\section{(2) 減衰に関する検討}

図9 は桁の中央の応答を示したものである。この結 果を桁をバネとダンパでつながれた質点系と考えたと きの滅衰定数にすると約 0.10 であり, 桁の減衰はかな ク大きいものとなっている. 松浦の数值計算では桁の減 衰定数の值は 0.02 から 0.06 までが用いられている ${ }^{2)}$. この 0.10 という值は大きいものであるが, 支間 $9 \mathrm{~m}$ のコンクリート橋で 0.13 という実測值の例もあり ${ }^{2)}$, 非現実的な値ではない。この減衰定数は離散化をした 式に加えた粘性項と桁の剛性により定めることができ る. 以下ではこの粘性項の係数を「粘性係数」,桁の減 衰定数を「減衰定数」と表現する。图-10は粘性は同じ 値にして,桁の剛性（桁高）をかえて行った計算の結果 である.これらをみると滅衰定数にするとすべてほほ同 じ值である．なお，変位の平衡点は静弾性問題の解から 求められる値と同じである.

図11は桁の剛性を同じ値にして, 粘性のみをかえて 計算したものである. 粘性係数が $3 \%$ のときは途中か ら不安定現象がおこる. 粘性係数が小さいときは不安定 現象もはやくからおこりはじめるが，その値を大きくす ると不安定現象がおきる時刻があとになり，その発散の 度合も少なくなる．桁は粘性係数が $3 \%, 5 \%$ のときを 比較すると，3\%のときのほうが若干大きいがほとんど 同じであり，隇衰定数もほほ同じである．しかし粘性係 数がさらに大きくなり $8 \%$ にもなると，減衰が大きく なる．さらにこのときは桁の応答が粘性係数が $5 \%$ の ときのような滑らかさではない

この数值計算の安定性を増すために導入した粘性倸
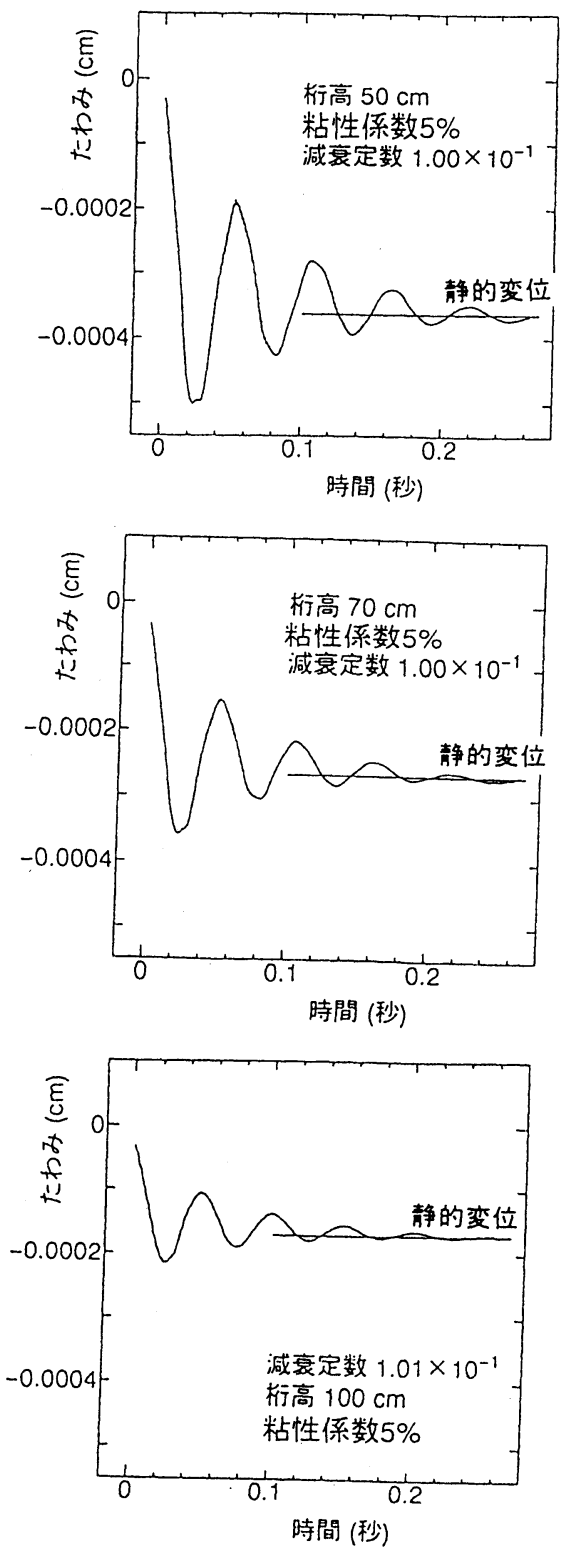

图-10㑉性をかえたときの桁中央部のステップ応答比較

数と構造物の減衰定数との関係については明確な理由 づけができておらず, 今後の検討課題と考えている. 粘 性係数 $5 \%$ のときが不安定にならずに，また滑らかな 応答が得られるので以降の計算ではその值とした。

\section{(3) 列車通過時の応答}

図-12 は支間 $5 \cdot \mathrm{m}$ のコンクリート桁橋を 4 両 編成の新幹線車両モデルと同じ軸配置を有する荷重列 を通過させたときの速度と衝咱率の関係を示したもの 

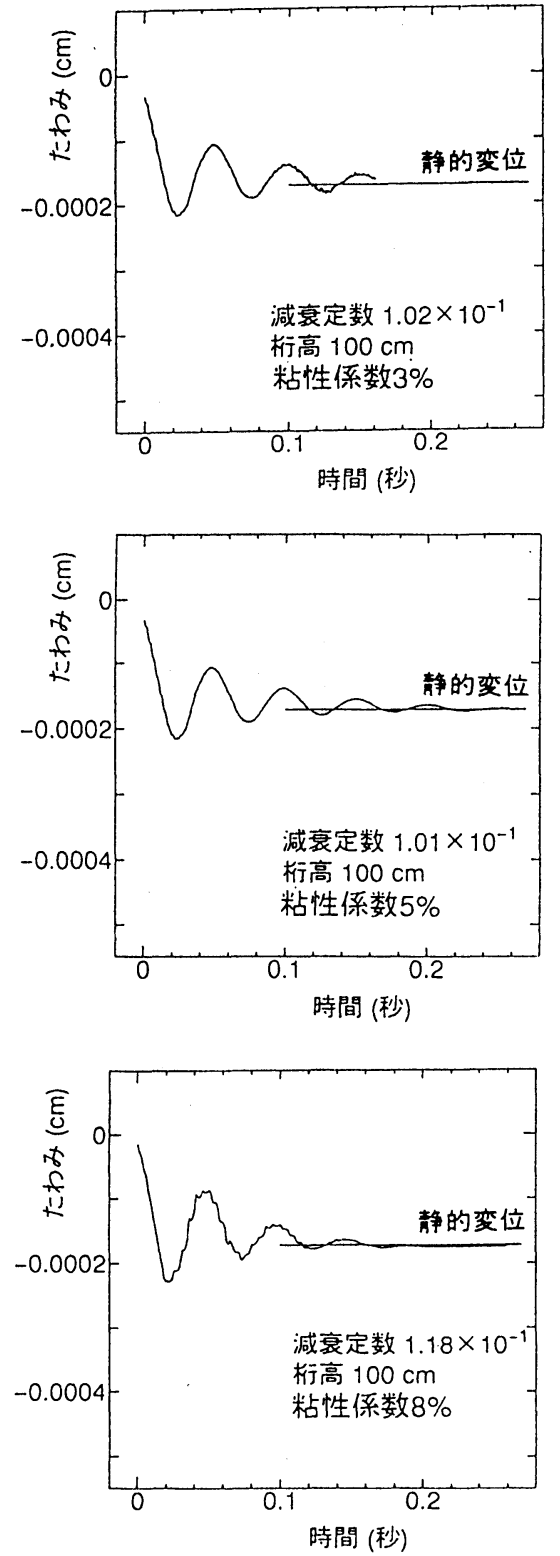

図-11 粘性をかえたときの桁中央部のステップ応答比較

である.この際, 列車は等荷重の移動連行荷重列として 計算を行っている.モード法において桁の減衰定数を $0.02,0.05,0.10$ と変化させてある. 林の減衰定数にはば らつきがあり，従来の研究においてもこれらの值が用い られる. 表-2はその諸元である. 時速 $200 \mathrm{~km}$ あたりに 小さく、時速 $450 \mathrm{~km}$ あたりにはやや大きく,そして時 速 $650 \mathrm{~km}$ あたりに大きく応答倍率のピークがみられ る. 先のステップ応答にもみられたが境界要素法から 得られた值は, 桁の減衰定数が 0.10 に相当するほど大

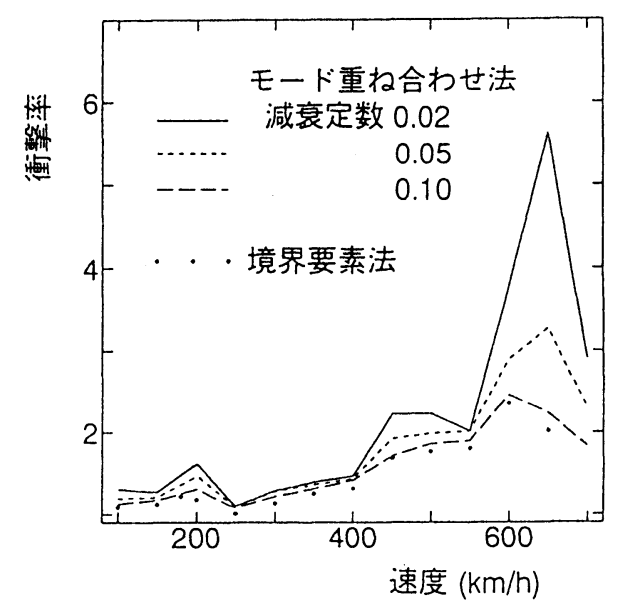

図-12 境界要素法で行った列車速度と衝慗率の関係

表-2 桁の諸元

\begin{tabular}{|c|c|c|c|}
\hline$\zeta$ & $m_{b}(\mathrm{t})$ & $c_{b}(\mathrm{~kg} \mathrm{sec} / \mathrm{cm})$ & $k_{b}(\mathrm{~kg} / \mathrm{cm})$ \\
\hline 0.02 & 37.5 & 202 & 666000 \\
\hline 0.05 & 37.5 & 505 & 666000 \\
\hline 0.10 & 37.5 & 1010 & 666000 \\
\hline
\end{tabular}

きりもので, モード重ね合わせ法における析の減衰定数 0.10 の場合とほほ同じ結果が得られる。

時速 $300 \mathrm{~km}, 500 \mathrm{~km}, 600 \mathrm{~km}$ の場合, 4 両編成の列 車が支間 $5 \mathrm{~m}$ のコンクリート桁橋を通過したときの桁 中央部上端のたわみの変動を図13 に示す. 時速 300 $\mathrm{km}$ の場合, 応答はそれほど大きいものではない. 80 のピークとなる部分があるが, これは台車が通過したと きである. 同一車両中の台車間は $15 \mathrm{~m}$ あり，橋長 $5 \mathrm{~m}$ より長く, 自由振動の部分が間に存在する.最大変位は 3 両目の通過時に生じる. 境界要素法からえられた衝撃 率の值は 1.18 , モード重极合わせ法で減衰定数が 0.02 のとき $1.28,0.05$ のとき $1.27,0.10$ のとき 1.21 である. 列車通過時の応答波形からもそれほどかわりがないこ とがわかる. それに対し，時速 $500 \mathrm{~km}$ の場合, 波形が $300 \mathrm{~km}$ に比べかなり異なっている.2,3,4の車両が通過 するときに大きな変位がみられる。衝整率は境界要素法 で 1.76 である.モード法で減衰定数が 0.10 のとき 1.86 である. 時速 $600 \mathrm{~km}$ の場合, 桁の振動は列車の進行と ともに增大し, 最大変位は最後の 4 両目の車両が通過 するときに生じる，変位は境界要素法で計算したもの のほうが小さいが, 衝慗率にすると 2.54 であり，またそ れに対してモード重ね合わせ法で行の減衰を 0.10 にし たときは 2.64 と,若干小さくなっている. 

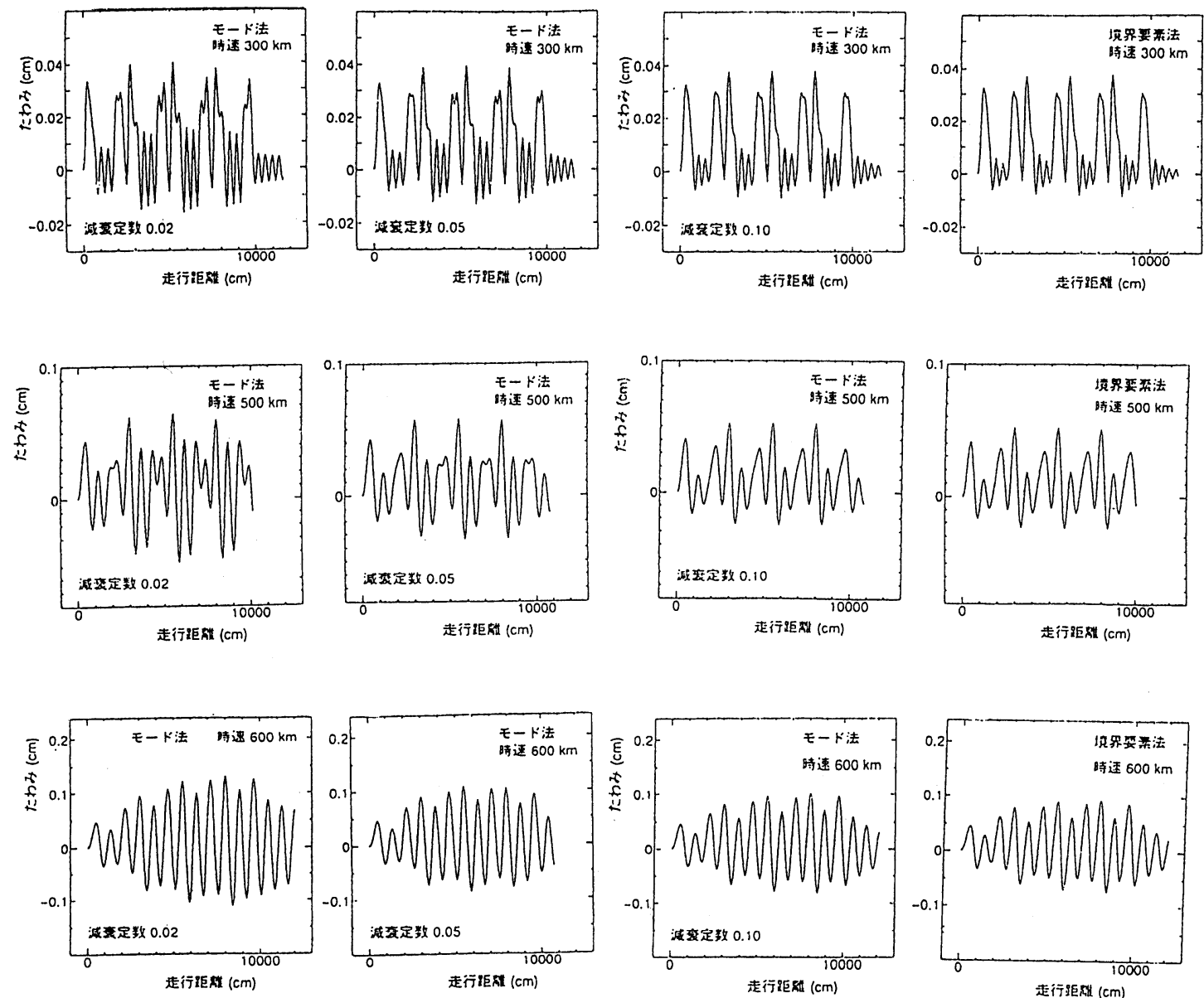

図-13 移動連行荷重列通過時の林スパン中央のたわみと第一荷重の走行距離との関係

\section{5.おわりに}

本研究では，桁に荷重が作用したことにより生じる， 波動伝播から振動までの現象を解析することを目的と し，境界要素法で列車の通過による橋梁の動的応答を副 算する方法を提案した，そして本手法と彷来の方法で あるモード重ね合わせ法との比較を行った，応答とし ては, 境界要素法で得られる結果は，設計には通常用い られる範囲より大きい值だが, モード重ね合わせ方にお いて桁の減衰定数を 0.10 としたとき, ある速度帯にお いて本手法による結果の方が若干衝慗率が小さくなる こともあったが、ほほ近い結果が得られることがわかっ た．本解析により，载荷直後に変形が波として伝播する 様子や, 載荷点近傍での変形の集中など, 桁の過渡的現 象を見ることができるようになった，また，境界要素法 での数值安定性に関し, 粘性項をとりいれ，その係数を かえることにより，その影響を調べた．その粘性の値と
桁の減衰特性の関係を調べることは今後の課題である. 列車通過の表し方に関しても，十分小さい時間きざみ幅 をとってはいるが, 方形荷重で表すことが誤差の生じる 原因となりうるのでさらに適切な表現方法を考える必 要がある。

\section{参考文献}

1）鉄道構造物設計標準·同解説, コンクリート構造物, pp.2731, 1992.

2）松浦 章夫: 高速鉄道における橋析の動的応答に関する研 究, 鉄道技術研究報告, No.1074 1978 .

3）涌井一小林 隆：高速鉄道におけるトラス部材の衝整 係数に関する理論的研究, 鉄道技術研究報告, No.1220 1982.

4) 涌井一，松本信之，田辺誠: 銑道車両と粠造物の動 的相互作用解析法に関する研究，鉄道総研報告，No.4. Vol.7.1993.

5) 涌井一, 鳥取誠一, 松本 信之, 奥田広之, 渡辺忠朋: 側 壁ビーム方式ガイドウェイの模造と動的応答特性, 鉄道 総研報告, No.1 Vol.5 1991.

6) A.C.Eringen and E.S.Suhubi:"Elastodynamics Vol 2," 
Academic Press 1975

7) 小林 昭一: 皘分方程式法(境界要素法) の発展, 土木学会 論文集, 第 350 号/I-2,1984.

8）岩崎 正二, 能町 純雄, 木田 哲量, 宮本 裕: 和文変換に よる格子平板の衝慗応答解析, 搆造工学論文集, Vol.37A 1991.

\title{
A STUDY ON DYNAMIC RESPONSE OF BRIDGE CAUSED BY LOADS IN LINE AT HIGH SPEED BY BOUNDARY ELEMENT METHOD
}

\author{
Hiromi SHIRAHATA, Chitoshi MIKI and Kazuo TATEISHI
}

High speed train imposes severe impact force on bridges. The magnitude of impact load has been analysed by modal superposition method, which indicates that extremely high impact force occurs when the speed of train gets over $300 \mathrm{~km} / \mathrm{hr}$. However, it isn't obvious whether this analysis method can apply properly in such case. In this study, boundary element method analyses were applied in order to investigate the dynamic behavior of bridge while high speed train runs above it. 